\title{
Competencies and Quantitative Techniques Possessed by Owners and Managers of SMEs in Uganda
}

\author{
Donatus Mugisha Rulangaranga (Corresponding author) \\ Department of Management Science, Makerere University Business School \\ P. O. Box 1337, Portbell Road, Nakawa, Kampala, Uganda
}

Tel: 256-700-783810Ｅ-mail: donatusmugisha2015@gmail.com

\begin{abstract}
Alain Vilard Ndi Isoh
Faculty of Business Management and Sustainability, ICT University, Cameroon

P. O. Box 526, Yaoundé, Cameroon
\end{abstract}

Tel: 237-71-808232Ｅ-mail: alainvilard.isoh@ictuniversity.org

\author{
Martha Abeja Ekure \\ Office of Dean of Students, Makerere University Business School, \\ P. O. Box 1337, Portbell Road, Nakawa, Kampala, Uganda \\ Tel: 256-772-695424Ｅ-mail: mabeja@mubs.ac.ug
}

Received: May 15, 2020 Accepted: June 7, 2020 Published: June 12, 2020

doi:10.5296/bms.v11i1.17037ＵRL: https://doi.org/10.5296/bms.v11i1.17037

\begin{abstract}
This study was carried out with an intention of establishing the competencies that managers and owners of SMEs possess in Uganda. Alongside that, the researchers also established the quantitative methods that are used in operations of SMEs in Uganda. The motivation of this study was to establish the extent to which owners and managers of SMEs act professionally even when the businesses they operate may not necessarily be formal. This was based on a review of literature indicating that about $90 \%$ of SMEs operating in Uganda are informal in nature facing similar challenges of short life span and unprofessional operational activities. Data was collected from 366 SMEs to be able to establish the two key aspects of focus of this
\end{abstract}


study. This represented $95 \%$ response rate out of 385 target sample expected to be covered at the beginning of the study. The unit of analysis was a single respondent who was either a manager or owner of a business while the sampling unit was an SME (entity). Findings indicated that despite the informal nature of SMEs in Uganda, they practice some level of professionalism in their operations as judged from the competencies identified and quantitative methods established as possessed and used in SMEs in Uganda.

Keywords: Competence, Competence of managers, managers and owners of SMEs, Competence of managers and owners of SMEs, Quantitative methods used in SMEs

\section{Introduction}

Quantitative methods are mathematical expressions that are mainly used in decision making. Though not commonly used in developing countries, most developed countries put their basis on these methods to ensure that the decisions taken are as objective as possible (Connell, 2016). The aspect of objectivity brings into context the need to allow data and information to give direction to a decision maker (Sebastianelli, 2018).

In business, these quantitative methods are used most of the time. The field that mostly makes use of these methods is finance. There are however other areas where quantitative methods apply in business such as production planning and human resource forecasting. In general, the quantitative methods are considered to be useful in enhancing business optimization in the different areas and aspects of business operations (Dogar \& Mare, 2014; Hosseini, Ivanov, \& Dolgui, 2019; Briskorn \& Dienstknecht, 2018). The different computations carried out in banks, budget units of government entities as well as simple traders have an element of quantitative methods. Some of these are complex statistical computations while others are simple and easy to use quantitative methods (Huarng, Rey-Martí, \& Miquel-Romero, 2018). The level of complexity notwithstanding, use of these quantitative methods is evident in business (Verma, 2016).

Though many businesses use quantitative methods in their operations, the situation may be different in SMEs. They may or may not be using quantitative methods in their operations though they are expected to have some level of competence (Lima, Crema, \& Verbano, 2019). This is dependent on the nature of business handled by the SMEs. Some business types require significant use of quantitative methods while others do not (Poufinas, Galanos, \& Papadimitriou, 2018).

In Uganda, SMEs are classified in different sectors. Majority are in the service sector. They are however existent in other fields such as commerce, trade and manufacturing. These SMEs form up to $90 \%$ of the private sector in Uganda signifying their importance in the country. This means that SMEs are indeed the engines of growth as they are considered to be in the country (Uganda Investment Authority, 2016).

Small and medium sized entities (SMEs) are part of the bigger family of businesses in the different countries of the world. Some of these SMEs manage to graduate into corporation 
while others fail (Muriithi, 2017). Further to that, most of these SMEs operate in an informal way (Wairimu, 2015). This therefore raises questions as to whether the people who operate these SMEs use quantitative techniques in decision making process.

In relation to using quantitative methods is the ability to use the techniques (Quantitative methods). This is the aspect of competence (Rulangaranga, Joseph, \& Moses, 2013). It is one thing having the methods at one's disposal and it is entirely another thing being able to use those methods. It is therefore important to note that evaluating competence to use quantitative methods is as important as evaluating the relevance of quantitative methods used in a business or organizational set up (Sudarmaji, Nawasiah, Thalib, \& Subhan, 2019). In this study, the focus was on a business set up at the level of SMEs.

\section{Literature Review}

Entrepreneurs develop ideas that turn into business. There are however other types of entrepreneurs that have the courage to manage a business that has already been established (Clark \& Harrison, 2019; Lounsbury, Cornelissen, Granqvist, \& Grodal, 2019). Managing a business requires one to have the necessary abilities to manage that business. These are referred to as competencies (Wyness \& Jones, 2019).

Different businesses require different competencies as presented by the needs in a business environment (Rulangaranga, Joseph, \& Moses, 2013; Pham \& Kim, 2019). Understanding of a business environment is therefore key in determining which competencies a business manager should have. Some businesses offer more or less necessities requiring less use of strategy in attracting customers (Charleston, Mattos, \& Chapman, 2018). For instance, businesses dealing in food put less effort in creating awareness of their existence since the actual and potential clients are already aware of their existence. This may not be the case for a new business that offers vehicles as their products.

Regardless of the type of business, there is need for one to have some level of competence as far as business management is concerned. This explains why human resource professionals demand for employee profile and past experience before recommending a person as the best candidate for a job. This clearly indicates the need to have competence as a business manager. The only challenge is whether business managers indeed have the needed competence level to manage the businesses that they do manage (Martin, Elg, Gremyr, \& Wallo, 2019).

Considering the nature of small and medium entities (SMEs), the aspect of favoritism is common. This means that a person is given a position to lead when he (or she) does not have the required competence levels. This therefore leaves the management of a business in a tricky position. Those in favor of this position however indicate the need to have a trustworthy person to manage a business rather than having a competent but untrustworthy person (Jackson, Amaeshi, \& Yavuz, 2008; Dowling, O’Gorman, Puncheva, \& Vanwalleghem, 2019).

The component of trust is important in business dealings. When there is trust, businesses 
thrive (Franklin \& Marshall, 2019). Though this is true, there is need to consider how this trust is established. Most times, in SMEs, trust is based on family ties (Dawson, Ginesti, \& Sciascia, 2019). This therefore means that the closely related with person is the most trusted of all. This is based on the ideology that a strong relation will handle a business as his or her business. This is expected to be reflected in the level of commitment and zeal that a person puts in a business as a business manager (González-Cruz \& Cruz-Ros, 2016). This however contravenes with a common business advice of not mixing business with family relations (Bauweraerts, Sciascia, Naldi, \& Mazzola, 2019). Accountants call this "The Business Entity Concept" (Bragg, 2019).

The element of trust basing on family relations is common in SMEs in different parts of the world. This is mainly as a result of the need to closely manage a business especially when it is still in its infancy level. Further to that, the aspect of trusting family relations enables a business owner to have a business manager without pay or with little allowances. This may not be the case if a business owner employees a person who is not a family relation. Though this attracts financial savings, it has its downside as far as the aspect of competence is concerned (Kudlats, McDowell, \& Mahto, 2019).

Competence of a business manager enables a business to tap into opportunities existent in a market area. This includes but not limited to determination of effective distribution channels and approaches, establishing better methods to market products, establishing methods to compute prices that are competitive in a market as well as planning where to buy from and how to transport goods to the point of sales. All these are decisions to be made that need someone competent to handle them. This therefore makes it necessary for every business to have someone competent to manage it (Coetzer, Susomrith, \& Ampofo, 2018).

Though the need to have competence is important in a business set up (Rulangaranga, Joseph, $\&$ Moses, 2013), there is need for available quantitative methods to be used so that proper management is in place. Ideally, when one is competent, he (or she) will make sure that the needed methods to ease his (or her) work are in place. This however may not always be the case. The probability of inexistence of the needed methods increases with the increasing levels of informality. This therefore means that there are high possibilities that SMEs may not be in possession of the needed quantitative methods for use in decision making (Lima, Crema, \& Verbano, 2019).

The focus on quantitative methods is key in the determination of competence in the context of SMEs because of the need to consider the concept of objectivity in the work of business managers. Quantitative techniques help a person to make informed decisions. These are decisions that are made based on available data. Cases of guess work or intuition are therefore minimized (Briskorn \& Dienstknecht, 2018).

Minimization of intuition in business management and business decision making helps to maximize objectivity. This means that prices will be set basing on available information and market conditions. The suppliers will be selected basing on the value addition they have to a 
particular SME (business). Employees too will be hired and relieved of their duties basing on their ability to add value to a business (Coetzer, Susomrith, \& Ampofo, 2018). All these things are difficult to do in the absence of data.

By its nature, data that is needed for business decision making is quantitative in nature. This is based on the fact that businesses are associated with finances, profits and value addition. All these concepts are quantitative in nature. Data could however be qualitative. In the context of business management however, the most needed data is quantitative (Dogar \& Mare, 2014).

Considering the context of Uganda, SMEs are mainly informal in their operations. Their management is therefore equally largely informal. There are however a few that formalize their operations (Wairimu, 2015). It is this informal nature that raises the question as to whether the managers and or owners use any quantitative techniques in the running of their businesses and whether the quantitative methods have any link to the competences they exhibit as they operate their businesses (Verma, 2016). This was the basis for conducting this study.

\section{Methodology}

This study focused on SMEs in Uganda. The informal nature of these SMEs was considered as the basis to establish whether the managers and or owners of SMEs have the needed competencies to manage those SMEs. The question of available quantitative methods was also raised on the same basis. A cross sectional research design was considered in this study.

The study focused on sample of 385 SMEs operating in the central region of Uganda. However, responses were obtained from 366 SMEs representing 95.1\% response rate. The focus on the central region was on the basis of volume of business. Though all regions have small businesses, most of them are found in the central region. Focusing on the central region therefore was representative enough for this study. Homogeneous purposeful sampling approach was considered when selecting the SMEs (Etikan, Musa, \& Alkassim, 2016). This was because of the focus of the study which made all SMEs homogeneous on that basis.

Data collection was done by means of questionnaires and interviews. Though majority of the responses were obtained through questionnaires, there are few responses that were obtained through interviews. These were responses from managers. The focus on managers was necessary for interview questions because there was a need to establish in detail their competence levels and the methods they have been using to manage the SMEs they were requested to manage.

Analysis was carried out following the thematic approach for interview responses. Descriptive analysis was also carried out using data obtained from questionnaire responses. This made it possible to obtain percentage composition of key characteristics about competencies and quantitative techniques used. The thematic analysis was necessary to pick out key issues from interview sessions with the managers and owners of SMEs in Uganda. 


\section{MlMacrothink}

\section{Findings and discussions}

Results from analysis reveal that $83.6 \%$ of SMEs surveyed were managed by the business owners while only $16.4 \%$ of them had managers to manage them. This conquers with the literature in the aspect of trust. Owners of SMEs in Uganda would rather manage their own businesses instead of allowing a third party do so (Nabuzale, 2017; Walusimbi, 2015).

On the aspect of informality, it was established that $55.2 \%$ of the businesses surveyed did not have any form of registration certificate and or license to operate. Only $44.8 \%$ were formerly registered. This reflects the aspect of informal nature of SMEs. In Kampala for instance, officials of Kampala Capital City Authority (KCCA) send in their security to forcefully close businesses that do not have a license (Nashonji, 2019). They always move with padlocks to close down these businesses until when they get an official receipt reflecting that the license fees are cleared. However, the operation of closing down businesses does not happen most of the time. This explains the possibility of some businesses (SMEs) being in position to operate without any form of license or registration certificate.

In relation to competences that are possessed by those who run these SMEs, findings in Figure 1 were obtained.

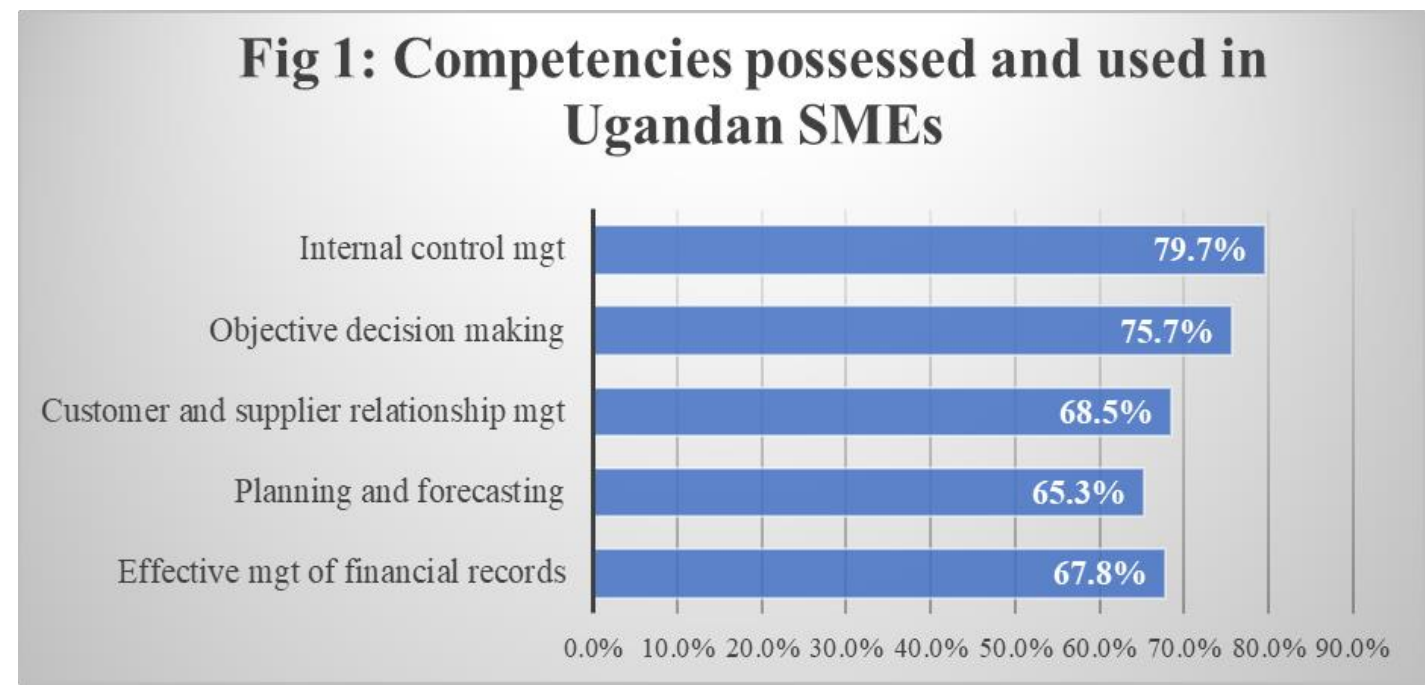

Source: Primary data

Findings in Figure 1 indicate that there are five main competencies established to be possessed by the managers and owners of SMEs. The competence that tops them all is that of internal control (79.7\%). This was mainly characterized by the ability to control inflows and outflows of commodities in a business. The least possessed competence is that of planning and forecasting $(65.3 \%)$.

The other competences are objective decision making, customer and supplier relationship management as well as management of financial records. This is a reflection that indeed, managers and owners of SMEs do not operate blindly despite the fact that most of them do not operate legally. This position can further be attributed to the many entrepreneurship 


\section{Macrothink}

Business Management and Strategy

ISSN 2157-6068

2020, Vol. 11, No. 1

trainings (Aspen Network of Development Entrepreneurs, 2018) that these businesses people get in the course of conducting their businesses.

In line with the trainings, the researchers wanted to establish whether the competencies possessed enabled the managers and owners of SMEs to use the different quantitative methods that are at their disposal. Using descriptive analysis, percentage usage of quantitative techniques was established. This is displayed in Figure 2.

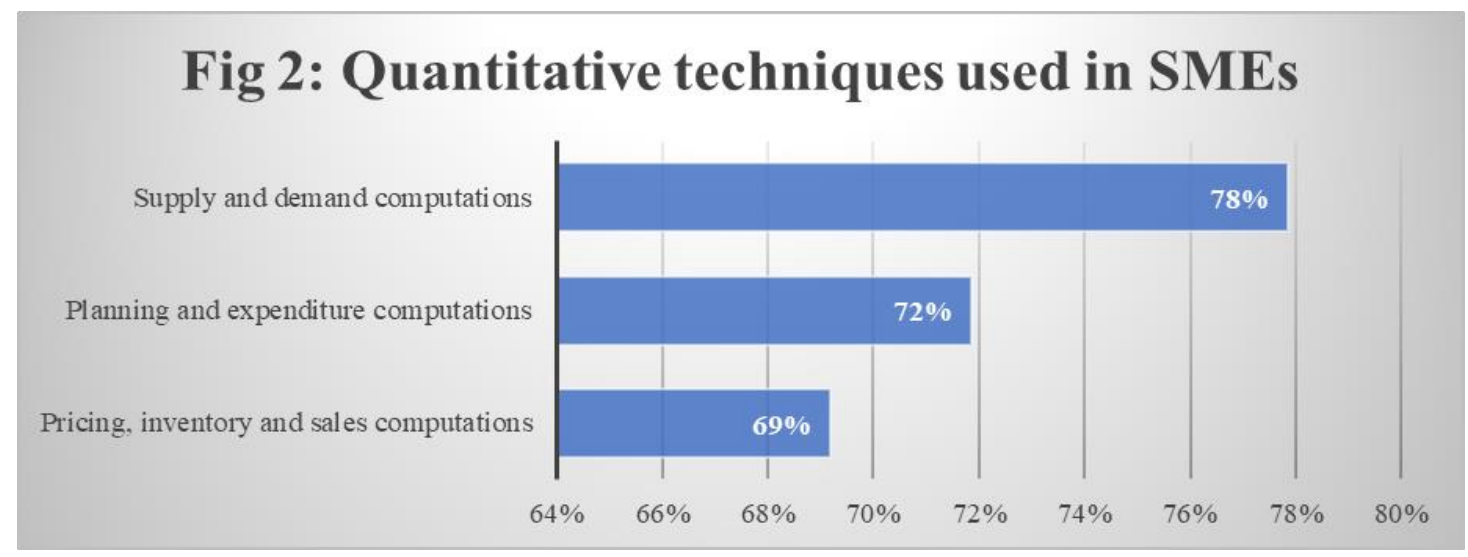

Source: Primary data

Findings in Figure 2 were further compared with the themes that were derived from the thematic analysis of interview data. This was necessary to establish consistency in the results. Basing on thematic analysis, findings in Figure 3 were obtained.

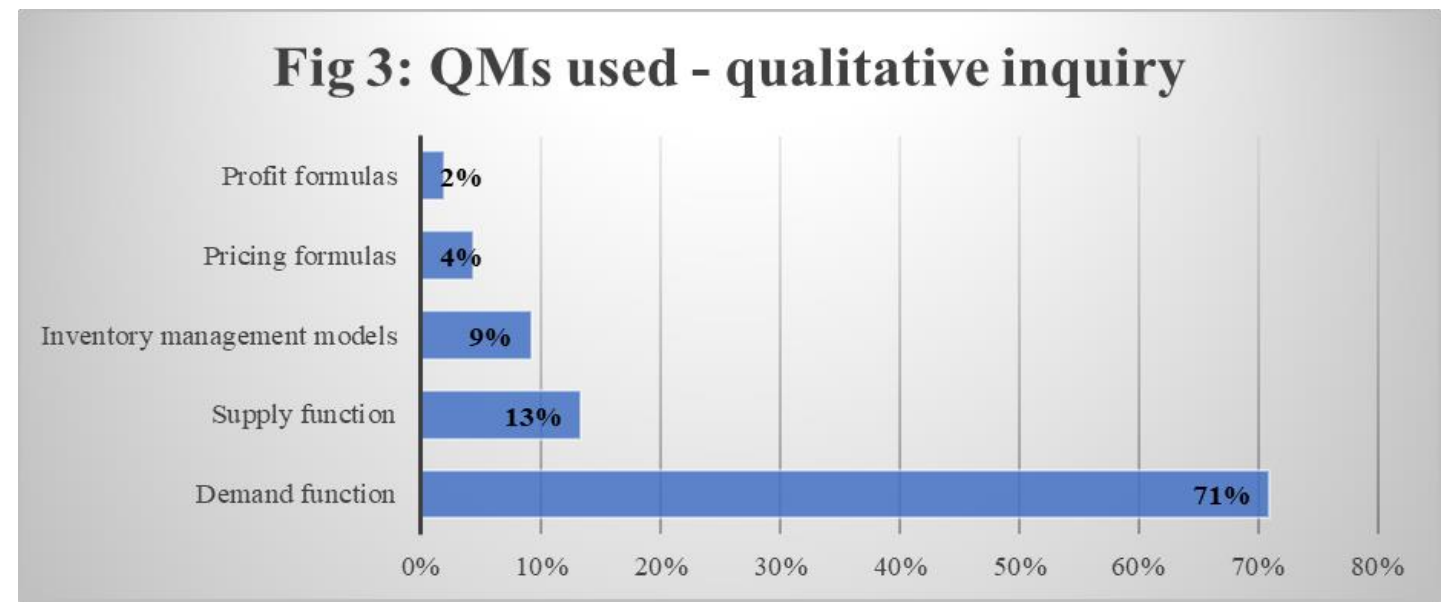

Source: Primary data

Findings presented in Figures 2 and 3 complement each other. Both indicate that demand and supply functions are the most used quantitative methods and or techniques in SMEs in Uganda. The owners and managers have to compute the quantities of items to purchase for resale every other time they go out to do the necessary purchases.

Pricing and inventory management computations are not as popular as they would be expected. This is because most of these SMEs deal in commodities that require serious 


\section{I Macrothink}

monitoring to avoid possible losses. Further to that, the managers and owners indicated that most of them have the competence of internal control [Ref: Fig 1]. This therefore leaves a gap as to how the internal control is done with less use of inventory management models. This finding further reflects the informal nature of SMEs in Uganda considering the fact that they indicate to be using internal control and yet the models expected to be used in this control are not put into use. This is similar to the position established in European countries as documented by Lima, Crema, \& Verbano (2019).

In the quest to understand more about the competencies possessed and quantitative methods (techniques) used, the respondents were requested to provide a response of how they learnt what they use in their businesses. Some indicated that they had to go for a training, while others indicated that they learnt informally on job. The details of this are provided in Figure 4.

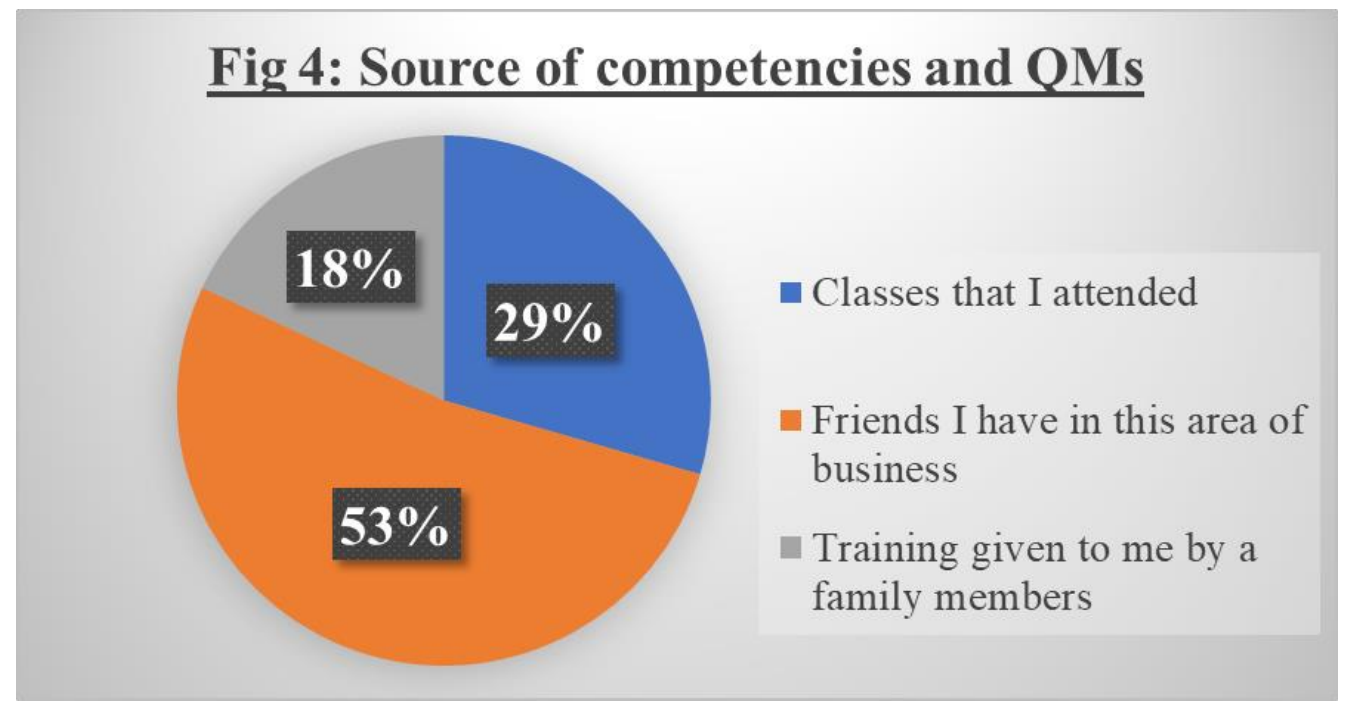

Source: Primary data

The findings in Figure 4 indicate that learning from friends in the same field of operation has been significant than learning from classes and family members. Though the latter two are equally important, the reality on ground indicates that peer training has been more effective to the SMEs operating in Uganda. Additionally, this finding indicates that most of those who establish SMEs begin as small and insignificant businesses but learn over time to become better and better. The owners and managers that fail to learn end up closing shop because of failure to manage their businesses.

Findings in relation to the source of knowledge as displayed in Figure 4 further indicate that the trainings provided by the government of Uganda have been effective so far. There are youth skilling programs (Mbabaali, 2018) as well as entrepreneurship trainings provided by Enterprise Uganda (Lyatuu, 2017). This is in addition to the many business clinics provided by different forums which help to gather owners and managers of SMEs. Though these forms of training by government are highlighted at this point, it is not conclusive as to whether they 
are the ones that enabled the managers and owners of SMEs get the competencies as well as the quantitative methods that they use in their businesses. This therefore presents another area that future research shall focus on as far as the SMEs in Uganda are concerned.

\section{Limitation}

The researchers did not get response on the issue of social relationship between the managers and owners of the SMEs surveyed. This response could have been useful to check whether the managers were hired basing on their competence or other factors. This shall however be handled in the subsequent research to be handled in this field of study.

\section{Conclusion and recommendation}

SMEs in Uganda have had numerous challenges. Overtime however, these challenges are gradually being ironed out. This does not mean that the SMEs are out of survival danger yet. The fact that the managers and owners of SMEs use professional skills in the process of managing their businesses is a big step in the right direction. Further enhancement is however needed to ensure that the quantitative methods (techniques) put to use are put to use in the right way. Basing on this, the following recommendations are suggested;

i) The managers and owners of SMEs need to be guided on how to effectively use the different quantitative methods (technique) that they currently use. This will enhance their overall impact in their various businesses.

ii) Considering that most managers and owners of SMEs learn from their peers, a cluster approach to training may be considered for future planned trainings targeting the owners and managers of SMEs

\section{References}

Aspen Network of Development Entrepreneurs. (2018). Uganda entrepreneurial ecosystem initiative: Phase I-Summary Report of Findings \& Recommendations . Kampala, Uganda: Center for Development Alternatives, Enterprise Uganda, Koltai and Company.

Bauweraerts, J., Sciascia, S., Naldi, L., \& Mazzola, P. (2019). Family CEO and board service: Turning the tide for export scope in family SMEs. International Business Review. https://doi.org/10.1016/j.ibusrev.2019.05.003

Bragg, S. (2019). Accounting tools.

Briskorn, D., \& Dienstknecht, M. (2018). Survey of quantitative methods in construction. Computers \& Operations Research, 194-207. https://doi.org/10.1016/j.cor.2017.11.012

Charleston, B., Mattos, H. G.-D., \& Chapman, M. (2018). Cross-cultural competence in the context of NGOs: bridging the gap between 'knowing' and 'doing'. The International Journal of Human Resource Management, 3068-3092. https://doi.org/10.1080/09585192.2016.1276469 
Clark, C. M., \& Harrison, C. (2019). Entrepreneurship: an assimilated multi-perspective review. Journal of Small Business \& Entrepreneurship, 43-71. https://doi.org/10.1080/08276331.2018.1446665

Coetzer, A., Susomrith, P., \& Ampofo, E. T. (2018). Opportunities to participate in formal and informal vocational learning activities and work-related outcomes in small professional services businesses. Journal of Vocational Education \& Training. https://doi.org/10.1080/13636820.2019.1584637

Connell, C. M. (2016). Introduction to quantitative methods. In L. A. Jason, \& D. S. Glenwick, Handbook of Methodological Approaches to Community-based Research. Oxford.

Dawson, A., Ginesti, G., \& Sciascia, S. (2019). Family-related antecedents of business legality: An empirical investigation among Italian family owned SMEs. Journal of Family Business Strategy. https://doi.org/10.1016/j.jfbs.2019.04.003

Dogar, C., \& Mare, C. (2014). Quantitative Methods for Sound Financial Management Decisions in Romanian European Social Fund Implementation. Procedia-Social and behavioral sciences, 290-294. https://doi.org/10.1016/j.sbspro.2013.12.459

Dowling, M., O’Gorman, C., Puncheva, P., \& Vanwalleghem, D. (2019). Trust and SME attitudes towards equity financing across Europe. Journal of World Business. https://doi.org/10.1016/j.jwb.2019.101003

Etikan, I., Musa, S. A., \& Alkassim, R. S. (2016). Comparison of Convenience Sampling and Purposive Sampling. American Journal of Theoretical and Applied Statistics, 5(1), 1-4. https://doi.org/10.11648/j.ajtas.20160501.11

Franklin, D., \& Marshall, R. (2019). Adding co-creation as an antecedent condition leading to trust in business-to-business relationships. Industrial Marketing Management, 170-181. https://doi.org/10.1016/j.indmarman.2018.10.002

González-Cruz, T. F., \& Cruz-Ros, S. (2016). When does family involvement produce superior performance in SME family business? Journal of Business Research, 1452-1457. https://doi.org/10.1016/j.jbusres.2015.10.124

Hosseini, S., Ivanov, D., \& Dolgui, A. (2019). Review of quantitative methods for supply chain resilience analysis. Transportation Research Part E: Logistics and Transportation Review, 285-307. https://doi.org/10.1016/j.tre.2019.03.001

Huarng, K.-H., Rey-Martí, A., \& Miquel-Romero, M.-J. (2018). Quantitative and qualitative comparative analysis in business. Journal of Business Research, 171-174. https://doi.org/10.1016/j.jbusres.2018.02.032

Jackson, T., Amaeshi, K., \& Yavuz, S. (2008). Untangling African indigenous management: Multiple influences on the success of SMEs in Kenya. Journal of World Business, 400-416. https://doi.org/10.1016/j.jwb.2008.03.002 
Kudlats, J., McDowell, W. C., \& Mahto, R. V. (2019). Unrelated but together: Trust and intergroup relations in multi-family businesses. Journal of Business Research, 750-756. https://doi.org/10.1016/j.jbusres.2018.12.073

Lima, P. F., Crema, M., \& Verbano, C. (2019). Risk management in SMEs: A systematic literature review and future directions. European Management Journal.

Lounsbury, M., Cornelissen, J., Granqvist, N., \& Grodal, S. (2019). Culture, innovation and entrepreneurship. Innovation, organization and management, 1-12. https://doi.org/10.1080/14479338.2018.1537716

Lyatuu, J. (2017). Enterprise Uganda takes business skills to the north. Retrieved from The Observer:

https://observer.ug/businessnews/55965-enterprise-uganda-takes-business-skills-to-the-north

Martin, J., Elg, M., Gremyr, I., \& Wallo, A. (2019). Towards a quality management competence framework: exploring needed competencies in quality management. Total Quality Management \& Business Excellence. https://doi.org/10.1080/14783363.2019.1576516

Mbabaali, D. (2018). Skilling Uganda: Are the objectives being met? Retrieved from Daily Monitor:

https://www.monitor.co.ug/News/Education/Skilling-Uganda-Are-objectives-being-met-/688 336-4857678-1284iyf/index.html

Muriithi, S. (2017). African Small and Medium Enterprises (SMEs) Contributions, Challenges and Solutions. European journal of research and reflection in Management Sciences.

Nabuzale, K. (2017). Promoting family businesses for an inclusive economic growth. Retrieved July 15, 2019, from New Vision: https://www.newvision.co.ug/new_vision/news/1456658/promoting-family-businesses-inclus ive-economic-growth

Nashonji, S. P. (2019). KCCA accused of "Bad Faith" in closing Kololo's Epicurien Restaurant. Retrieved from Chimpreports: https://chimpreports.com/kcca-accused-of-bad-faith-in-closing-kololos-epicurien-restaurant/

Pham, H., \& Kim, S.-Y. (2019). The effects of sustainable practices and managers' leadership competences on sustainability performance of construction firms. Sustainable Production and Consumption, 1-14. https://doi.org/10.1016/j.spc.2019.05.003

Poufinas, T., Galanos, G., \& Papadimitriou, P. (2018). The competitiveness of Small and Medium Enterprises in Adverse Economic Environments. Scientific Research Publishing-Theoretical Economic Letters. https://doi.org/10.4236/tel.2018.813175 
Rulangaranga, D. M., Joseph, N., \& Moses, M. (2013). Competence and ethical behavior of people appointed to contract management post in local governments in Uganda. European Journal of Business and Management, 5(9).

Sebastianelli, R. (2018). Multiple student learning objectives in basic business statistics: Strategies, assessment, and recommendations. Journal of Education for Business, 341-352. https://doi.org/10.1080/08832323.2018.1493421

Sudarmaji, E., Nawasiah, N., Thalib, S., \& Subhan, M. N. (2019). The Individual Competencies and Ambidexterity Organization Capability: Indonesian SMEs Perspective. Asia proceedings of social sciences. https://doi.org/10.31580/apss.v3i1.378

Uganda Investment Authority. (2016). SMEs driving the economy. Retrieved May 2019, from https://www.ugandainvest.go.ug/smes-driving-economy/

Verma, G. (2016). Quantitative techniques in business. International journal of research science and management.

Wairimu, W. W. (2015). Micro, Small and Medium Sized Enterprises as suppliers to the extractive industry. UNDP.

Walusimbi, R. (2015). Uganda: Key Elements of Family Businesses. Retrieved from allAfrica.

Wyness, L., \& Jones, P. (2019). Boundary crossing ahead: perspectives of entrepreneurship by sustainability educators in higher education. Journal of Small Business \& Entrepreneurship, 183-200. https://doi.org/10.1080/08276331.2018.1493338

\section{Copyright}

Copyright for this article is retained by the author(s), with first publication rights granted to the journal.

This is an open-access article distributed under the terms and conditions of the Creative Commons Attribution license (http://creativecommons.org/licenses/by/4.0/). 